Institute and Faculty of Actuaries

ISSN 1748-4995

\title{
Annals of Actuarial Science
}

VOLUME 5 - PART 1 


\title{
Institute and Faculty of Actuaries
}

\author{
Maclaurin House \\ Staple Inn Hall \\ Napier House \\ 18 Dublin Street \\ Edinburgh $\cdot$ EH1 3PP \\ High Holborn \\ 4 Worcester Street \\ London · WC1V 7QJ \\ Oxford · OX1 2AW
}

Editor: Angus Macdonald, BSc, PhD, FFA, FRSE

Associate Editors:

Anthony Asher, BBusSc, FIA, FIAA

David Muiry, MB, BS, FASI, FIA

Philip Booth, BA, FSS, FIA

David Paul, BSc, FFA

Andrew Cairns, MA, PhD, MIMA, CMath, FSS, FFA

Robert Thomson, PhD, FASSA

David Dickson, BSc, PhD, FIAA, FFA

Peter Tompkins, MA, FIA

David Forfar, MA, FIMA, CMath, FFA

Mark Trayhorn, MSc, FIA

Lane Hughston, DPhil

Richard Verrall, Hon FIA

Malcolm Kemp, MA, FIA

Howard Waters, MA, DPhil, FIA, FFA

\begin{abstract}
Subscriptions
Annals of Actuarial Science is published twice a year in the spring and autumn by Cambridge University Press for the Institute and Faculty of Actuaries. The 2011 subscription price is $£ 110$ (US\$187) for print and electronic access. The electronic-only rate is $£ 96$ (US\$164).

Cambridge University Press also publishes the British Actuarial Journal for the Institute and Faculty of Actuaries. A bundled subscription to both journals is available at $£ 175$ (US\$298) for print and electronic access. The electronic-only rate is $£ 155$ (US\$264). The British Actuarial Journal is also available as a standalone subscription at the same prices as the Annals of Actuarial Science above. All prices include delivery by air if appropriate, and exclude VAT. EU subscribers (outside the UK) who are not registered for VAT should add VAT at their country's rate. VAT registered members should provide their VAT registration number. Japanese prices for institutions (including ASP delivery) are available from Kinokuniya Company Ltd, P.O. Box 55, Chitose, Tokyo 156, Japan.

Orders, which must be accompanied by payment, may be sent to a bookseller, subscription agent or direct to the publisher: Cambridge University Press, The Edinburgh Building, Shaftesbury Road, Cambridge CB2 8RU, UK, email journals@cambridge.org or in the USA, Canada and Mexico: Cambridge University Press, Journals Fulfillment Department, 100 Brook Hill Drive, West Nyack, New York 10994-2133, email subscriptions_ newyork@cambridge.org. Copies of the Journal for subscribers in the USA, Canada and Mexico are sent by air to New York to arrive with minimum delay. Postmaster: send address changes in USA, Canada and Mexico to Africa, Journals Fulfillment Department, 100 Brook Hill Drive, West Nyack, New York 10994-2133; or e-mail subscriptions_newyork@cambridge.org. Claims for missing issues will only be considered if made immediately on receipt of the subsequent issue.
\end{abstract}

\section{Copying}

All rights reserved. No part of this publication may be reproduced in any form or by any means, photocopying, electronic, or otherwise, without permission in writing from Cambridge University Press. Permission inquiries from the USA, Mexico, and Canada should be addressed to the New York office of Cambridge University Press http:// www.cambridge.org/us/information/rights/contacts/newyork.htm; permission inquiries from elsewhere should be addressed to the Cambridge office http://www. cambridge.org/uk/information/rights/contacts/cambridge.htm; permission inquiries from Australia and New Zealand should be addressed to the Melbourne office http://www. cambridge.org/aus/information/contacts_melbourne.htm. Permission to copy (for users in the USA) is available from the Copyright Clearance Center (CCC), http://www.copyright.com, email: info@copyright.com. Specific written permission must be obtained for republication; contact the nearest Cambridge University Press office.

\section{Advertising}

To advertise in the journal please contact the relevant Advertising Promoter for your area: in the USA, Canada or Mexico: journals_advertising@cup.org or telephone +1 (212) 337 5053; in the UK, Europe or rest of the world: ad_sales@cambridge.org or telephone +44 (1223) 325083.

(C) Institute and Faculty of Actuaries

Annals of Actuarial Science is included in the Cambridge Journals Online service which can be found at http:// journals.cambridge.org/aas. 